Abstract-In the U.S. Gulf of Mexico (GOM), red snapper (Lutjanus campechanus) are managed as a unit stock, although the stock is assessed as subunits east and west of the Mississippi River. Differences were examined between management subunits by comparison of the size and age structure and growth rates of red snapper among recreational catches from 6 regions of the GOM: South Texas, North Texas, Louisiana, Alabama, Northwest Florida, and Central Florida. In all of these regions, red snapper sampled in 2009 and 2010 were small and predominantly from age classes that represented the strong recruitment for the year classes of 2004-06. As such, our data indicate a highly truncated age structure with few fish older than 6 years. Demographic differences in size, age, and growth parameters were found. Small $(\leq 550$ $\mathrm{mm}$ in total length), fast-growing individuals dominated the catches in South Texas and the regions of Florida, whereas larger, slower-growing fish represented the majority of catches in Alabama and Louisiana. The potential mechanisms affecting observed demographic variation include environmental differences, fishing pressure, habitat preference, and management regimes; however, no definitive conclusion about cause and effect can be made. The combination of demographic differences between regions and consistent occurrence of the strong year classes GOM-wide supports recent conclusions that red snapper form a metapopulation of semi-isolated assemblages in the GOM.

Manuscript submitted 25 April 2013. Manuscript accepted 30 July 2014. Fish. Bull. 112:261-273 (2014). doi:10.7755/FB.112.4.3

The views and opinions expressed or implied in this article are those of the author (or authors) and do not necessarily reflect the position of the National Marine Fisheries Service, NOAA.

\title{
Regional differences in the age and growth of red snapper (Lutjanus campechanus) in the U.S. Gulf of Mexico
}

\author{
Courtney R. Saari (contact author) ${ }^{1}$ \\ James H. Cowan Jr. ${ }^{1}$ \\ Kevin M. Boswell2
}

Email address for contact author: courtney.saari@noaa.gov

${ }^{1}$ Department of Oceanography and Coastal Sciences

Louisiana State University

Energy, Coast and Environment Building

Baton Rouge, Louisiana 70803

Present address for contact author: IAP Worldwide Services Inc. Southeast Fisheries Science Center National Marine Fisheries Service, NOAA 75 Virginia Beach Drive Miami, Florida 33156

2 Department of Biological Sciences

Florida International University

Biscayne Bay Campus

3000 NE $151^{\text {st }}$ Street

North Miami, Florida 33181

The stock of red snapper (Lutjanus campechanus) in the U.S. Gulf of Mexico (GOM) has been exploited since the mid-1800s, and the red snapper fishery is still one of the most economically important reef fish fisheries in the GOM. This fishery has multimillion-dollar commercial and recreational sectors and is affected by juvenile mortality that results from bycatch in the shrimp trawl fishery. Since the early 1990s, GOM red snapper have been managed intensely as a single-unit stock through both frequent management intervention and significant catch constraints. However, this stock has been declining since the 1970 s and was overfished for most of the 1990s and 2000s (Goodyear, 1997; SEDAR $^{1}$; Porch, 2007; GMFMC ${ }^{2}$;

${ }^{1}$ SEDAR (SouthEast Data, Assessment, and Review). 2005. Stock assessment report of SEDAR 7: Gulf of Mexico red snapper, 480 p. [Available from http:// www.sefsc.noaa.gov/sedar/.]

${ }^{2}$ GMFMC (Gulf of Mexico Fishery Management Council). 2007. Final Amendment 27 to the Reef Fish Fishery
NMFS $^{3}$ ). The current management policy has set a rebuilding plan for stock recovery by 2032 , and the most recent stock assessments indicate that, although this stock is overfished, overfishing is no longer occurring $\left(\right.$ GMFMC $^{4}$; SEDAR $\left.{ }^{5}\right)$.

Management Plan and Amendment 14 to the Shrimp Fishery Management Plan, 480 p. [Available from Gulf of Mexico Fishery Management Council, 2203 North Lois Ave., Suite 1100, Tampa, FL 33607.]

${ }^{3}$ NMFS (National Marine Fisheries Service). 2012. Annual report to Congress on the status of U.S. fisheries-2011, 20 p. [Available from NMFS, NOAA, 1315 East-West Hwy., Silver Spring, MD 20910.]

${ }^{4}$ GMFMC (Gulf of Mexico Fisheries Management Council). 2010. Final regulatory amendment to the Reef Fish Fishery Management Plan to set total allowable catch for red snapper, $98 \mathrm{p}$. [Available from Gulf of Mexico Fishery Management Council, 2203 North Lois Ave., Suite 1100, Tampa, FL 33607.]

5 SEDAR (SouthEast Data, Assessment, and Review). 2013. SEDAR 31-Gulf of Mexico red snapper stock assessment report, 1103 p. [Available from http:// www.sefsc.noaa.gov/sedar/.] 
Although red snapper in the GOM currently are managed as a single unit stock, separate stock assessments have been conducted since 2004 for subunits east and west of the Mississippi River (SEDAR ${ }^{1}$ ). Under the single-unit-stock hypothesis, no significant differences are assumed in population structure (genetics and population demographics) across the GOM. The single-unit-stock assumption has been supported by genetic analysis (Camper et al., 1993; Gold et al., 1997; Gold et al., 2001; Saillant et al., 2010), by the potential for high larval dispersal through hydrodynamic transport (Johnson et al., 2009), and by the capacity of adult red snapper to move great distances $(>100 \mathrm{~km})$ and, therefore, to potentially maintain mixing rates (Patterson et al., 2001a). Also, in the past 20 years, 2 strong year classes (1989 and 1995) were found to dominate catches GOM-wide (Allman and Fitzhugh, 2007), strengthening the single-unit-stock hypothesis.

In the recent decade, however, numerous studies have highlighted spatial differences in age, growth, and reproductive demographics between eastern and western red snapper (Allman et al., 2002; Fischer et al., 2002, 2004; Jackson et al., 2007). Studies of the population structure of red snapper genetics and movement indicate that GOM fish form a metapopulation of semiisolated, subpopulations (Saillant and Gold, 2006; Gold and Saillant, 2007; Patterson, 2007), and recent genetic evidence indicates that the Caribbean red snapper $(L$. purpureus) and the red snapper (L. campechanus) may not be separate species (Gold et al., 2011; Gomes et al., 2012). Examination of otolith microchemistry also has shown region-specific natural tags or elemental signatures, which have been used to identify nursery sources, subpopulations, and to provide evidence of stock mixing across the GOM (Patterson et al., 2008; Nowling et al., 2011; Sluis et al., 2012).

In this study we sought to complement similar measures reported by Fischer et al. (2004) for a previous study and to expand upon the area that they studied in order to encompass more regions. The updated information from our study is important for identification of region-specific trends and changes in the red snapper fishery. Our objectives were 1) to examine the size structure, growth rates, and size at age of red snapper in the GOM to elucidate trends in demographic differences noted in the most recent stock assessments (SE$\mathrm{DAR}^{5}$ ), 2) to expand the comparison to incorporate red snapper off Florida, and 3) to identify region-specific trends in the recreational red snapper fishery.

\section{Materials and methods}

Red snapper were sampled from recreational hookand-line fisheries (head boats and charter boats) in 6 regions of the GOM during 2009 and 2010 (Fig. 1) and were identified by using characteristics from Hoese and Moore (1998). In each region and year, a maximum of 200 fish were sampled from the daily catches of recre- ational vessels. Fish were selected haphazardly while the vessels offloaded. Sample size varied with trip size, and the number of vessels sampled in each region was dependent upon the size of the regional fleet. To obtain samples representative of the fishery in each region and to maximize the number of vessels and trips sampled, collection occurred during a period of 3-5 days each year. Samples were not selected from the commercial fishery because of the market preference for fish close to $330 \mathrm{~mm}$ in total length. During 2010, recreational fisheries in Alabama and Louisiana were not sampled because these fisheries were closed as a result of the Deepwater Horizon Oil Spill. Louisiana samples were supplemented in 2010 with fish collected by hook and line from 2 oil platforms, which are sites routinely fished by recreational and commercial fishermen, in the GOM about $110 \mathrm{~km}$ south of the Louisiana coast. For all fish collected, morphometric measurements (natural total length [TL] in millimeters and total weight [TW] in kilograms) were recorded, sex was determined by macroscopic examination of gonads (when possible), and sagittal otoliths were removed, rinsed, and stored in coin envelopes until processed.

The left sagittal otolith was sectioned in a transverse plane following the methods of Cowan et al. (1995) with a Hillquist Thin Section Machine, Model $800^{6}$ (Hillquist Inc., Denver, CO), equipped with a diamondembedded wafering blade and precision grinder. Otolith sections $(0.2-\mathrm{mm}$ thick) were read under a dissecting microscope with transmitted light and a polarizing light filter at a magnification from $20 \times$ to $64 \times$. Counts of opaque annuli were made along the dorsal margin of the sulcus acousticus from the core to the proximal edge (Wilson and Nieland, 2001). Edge condition of the dorsal margin was coded according to Beckman et al. (1988). Annuli were counted by 2 independent readers without knowledge of date and location of capture or access to morphometric data of the specimens. When initial counts disagreed, annuli were counted a second time. In instances where a consensus between the 2 readers could not be reached, the annulus counts from the more experienced reader were reported. Precision between readers was evaluated with the coefficient of variation (CV), index of precision (D) (Chang, 1982), and average percent error (APE) (Beamish and Fournier, 1981). Ages of red snapper were estimated from the number of opaque annuli, assumed birthdate, and capture date, by following the equation described by Wilson and Nieland (2001):

$$
\begin{aligned}
\text { Age }(\text { days }) & =-182+(\text { annulus count } \times 365) \\
& +((m-1) \times 30)+d,
\end{aligned}
$$

where $m=$ the ordinal number (1-12) of month of capture; and

\footnotetext{
${ }^{6}$ Mention of trade names or commercial companies is for identification purposes only and does not imply endorsement by the National Marine Fisheries Service, NOAA.
} 


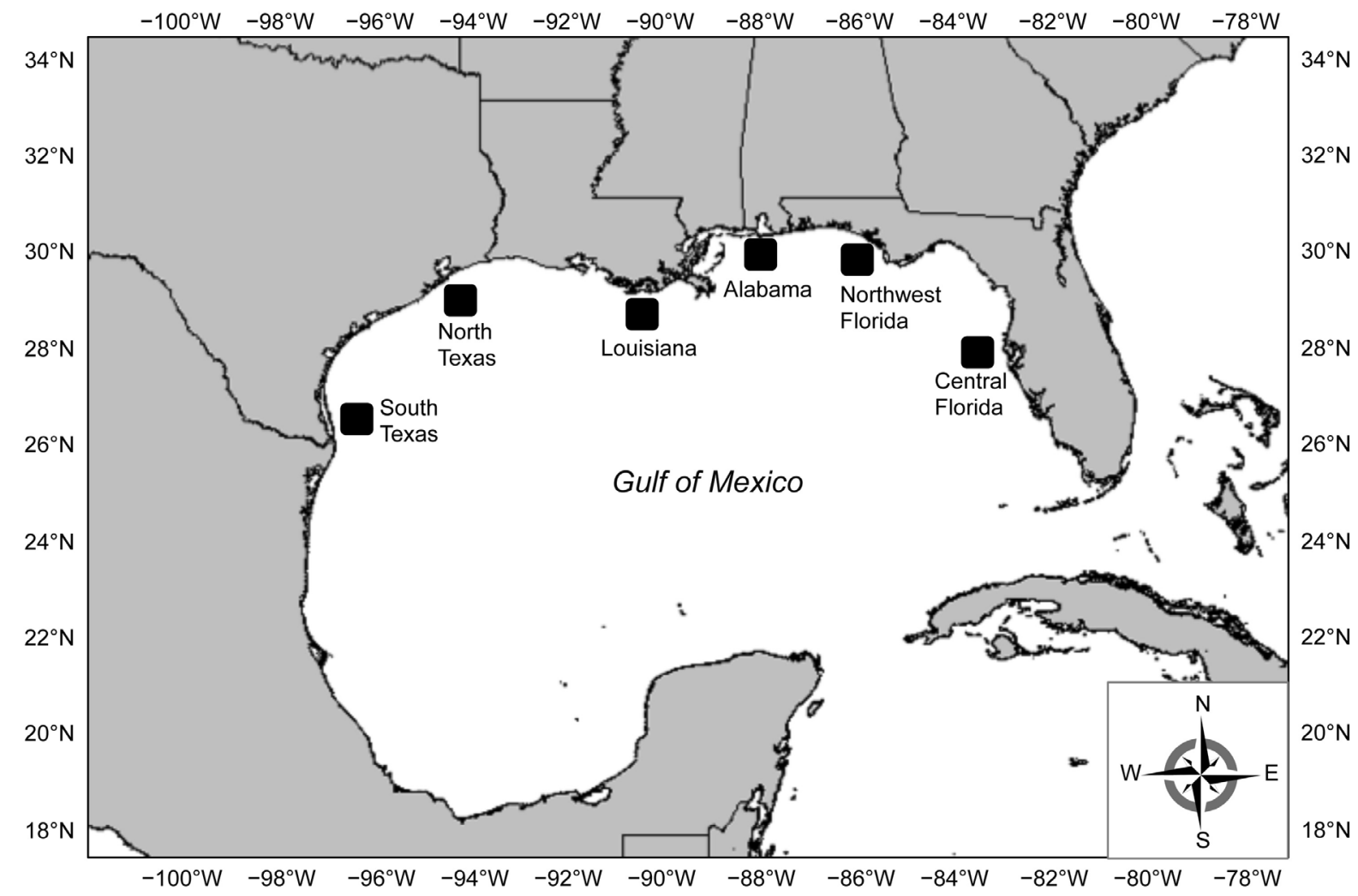

Figure 1

Map of the Gulf of Mexico showing the 6 regions where red snapper (Lutjanus campechanus) were collected for age and growth analysis from recreational catches in 2009 and 2010. The 6 regions were South Texas, North Texas, Louisiana, Alabama, Northwest Florida, and Central Florida.

$d=$ the ordinal number (1-31) of the day of the month of capture.

It was assumed that annulus formation began on 1 January, and the periodicity of opaque zone formation was verified with edge analysis (Wilson and Nieland, 2001; Fischer et al., 2004). To account for the uniform birthdate of 1 July, 182 days were subtracted from each age estimate.

Analysis of variance (ANOVA) was used to compare mean TL, TW, and age among regions, and all statistical analyses were performed with SAS analytics software, vers. 9.1.3 (SAS Institute Inc., Cary, NC). TL, TW, and age data were first transformed with natural $\operatorname{logs}(\ln )$ to meet the assumptions of normality and homogeneity of variance. Tukey's honestly significant difference (HSD) test was used for post-hoc pairwise comparisons. Frequency distributions of size and age were compared by region with the Kolmogorov-Smirnov 2-sample (KS) test (Tate and Clelland, 1957). A chi-square $\left(\chi^{2}\right)$ test was used to determine whether sex ratios differed from a 1:1 ratio, overall and by region. Relationships of TW to TL were described first by fitting a linear regression to the ln-transformed variables and then by obtaining estimates (from the fitted regression coefficients) that corresponded to the parameters of the power function of $T W=a T L^{b}$. Analysis of covariance (ANCOVA) was used to compare the linearized slopes and intercepts among the regions.

Mean size at age (weighted by sample size) of the most common ages (3-7 years) was compared through the use of ANOVA with a Tukey's HSD test for post-hoc comparisons. Growth was modeled for observed TL and TW at age with von Bertalanffy growth equations, and tested for coincident curves with likelihood ratio tests (Kimura, 1980; Haddon, 2001) and Bonferroni's correction for multiple pairwise comparisons. Growth models were fitted with nonlinear regression by least squares in the following form:

$$
\begin{gathered}
T L_{\mathrm{t}}=L_{\infty}\left(1-\mathrm{e}^{-k(t)}\right), \\
T W_{\mathrm{t}}=W_{\infty}\left(1-\mathrm{e}^{-k(t)}\right)^{\mathrm{b}},
\end{gathered}
$$

where $T L_{\mathrm{t}}=$ TL at age $t$;

$$
\begin{aligned}
T W_{\mathrm{t}} & =\mathrm{TW} \text { at age } t \\
L_{\infty} & =\mathrm{TL} \text { asymptote; } \\
W_{\infty} & =\mathrm{TW} \text { asymptote; } \\
k & =\text { growth coefficient; } \\
t & =\text { age in years; and } \\
b & =\text { exponent derived from TW-TL regressions. }
\end{aligned}
$$




\section{Table 1}

Numbers of red snapper (Lutjanus campechanus) sampled in 2009 and 2010 for age and growth analysis from recreational catches in 6 regions of the Gulf of Mexico: South Texas, North Texas, Louisiana, Alabama, Northwest Florida, and Central Florida.

\begin{tabular}{lrrcr}
\hline Region & Males & Females & Unknown sex & Total \\
\hline South Texas & 134 & 191 & 23 & 348 \\
North Texas & 111 & 93 & 20 & 224 \\
Louisiana & 131 & 132 & 5 & 268 \\
Alabama & 93 & 108 & 3 & 204 \\
Northwest Florida & 186 & 254 & 23 & 463 \\
Central Florida & 105 & 161 & 34 & 301 \\
$\quad$ Total & 761 & 938 & 108 & 1808 \\
& & & & \\
\end{tabular}

Models were forced through $t_{0}=0$ for comparison purposes because of a lack of small, young ( $<2$ years old) individuals in all sample populations. For all statistical tests, significance was measured at an alpha level of 0.05 .

\section{Results}

From 6 major recreational regions of the GOM, 1808 red snapper were sampled and a male-to-female ratio of 0.81:1.00 was calculated (Table 1). Among all regions, the majority of fish were small: mean TL of $540.19 \mathrm{~mm}$ (standard error [SE] 2.17) and mean TW of $2.40 \mathrm{~kg}$ (SE $0.04)$. On average, fish from Alabama were the largest fish, and the smallest fish were from the Florida regions (Table 2). Frequency distributions of TL and TW were significantly different among the regions; the largest proportion of small $(<550 \mathrm{~mm}$ TL and $<2.5 \mathrm{~kg})$ fish were found in Northwest Florida (Fig. 2). No significant differences were noted between the sexes in the TL and TW frequency distributions (KS test: $P=0.49$ and $P=0.65$ ) and means (Tukey HSD test: $P=0.68$ and $P=0.92$ ).

Significant differences in TW-TL regression models were detected among the regions (ANCOVA test of

\section{Table 2}

Minimum, maximum, and mean values of (A) total length (TL), in millimeters, (B) total weight (TW), in kilograms, and (C) age, in years, of red snapper (Lutjanus campechanus) sampled from recreational catches in 6 regions of the Gulf of Mexico in 2009 and 2010. The 6 regions were South Texas, North Texas, Louisiana, Alabama, Northwest Florida, and Central Florida. Each section of this table is arranged in increasing order of mean values. Superscript letters indicate significant differences $(<0.05)$ among the means. Within each row, means not connected with the same letter are significantly different (least-square means with Tukey's honestly significant different adjustment). Standard errors of the mean (SE) are provided in parentheses.

\begin{tabular}{|c|c|c|c|c|c|c|}
\hline $\mathbf{A}$ & $\begin{array}{l}\text { Northwest } \\
\text { Florida }\end{array}$ & $\begin{array}{l}\text { North } \\
\text { Texas }\end{array}$ & $\begin{array}{l}\text { Central } \\
\text { Florida }\end{array}$ & $\begin{array}{l}\text { South } \\
\text { Texas }\end{array}$ & Louisiana & Alabama \\
\hline$n$ & 435 & 223 & 298 & 332 & 268 & 204 \\
\hline Min TL & 389 & 410 & 394 & 406 & 400 & 426 \\
\hline Max TL & 880 & 900 & 780 & 722 & 821 & 880 \\
\hline Mean TL & 497.15 & 525.94 & 530.43 & 552.10 & 560.81 & 604.19 \\
\hline \multirow[t]{2}{*}{ (SE) } & $(3.90)^{a}$ & $(6.63)^{b}$ & $(5.08)^{b}$ & $(4.34)^{c}$ & $(5.24)^{c}$ & $(5.26)^{d}$ \\
\hline & Northwest & North & Central & & South & \\
\hline B & Florida & Texas & Florida & Louisiana & Texas & Alabama \\
\hline$n$ & 388 & 203 & 265 & 193 & 318 & 178 \\
\hline Min TW & 0.64 & 0.84 & 0.64 & 0.87 & 0.64 & 1.04 \\
\hline Max TW & 9.16 & 10.25 & 7.52 & 8.71 & 9.22 & 12.7 \\
\hline Mean TW & 2.10 & 2.18 & 2.21 & 2.45 & 2.54 & 3.28 \\
\hline \multirow[t]{2}{*}{$(\mathrm{SE})$} & $(0.08)^{a}$ & $(0.11)^{a}$ & $(0.08)^{a}$ & $(0.10)^{b}$ & $(0.60)^{b}$ & $(0.10)^{c}$ \\
\hline & Central & Northwest & & North & & South \\
\hline $\mathbf{C}$ & Florida & Florida & Louisiana & Texas & Alabama & Texas \\
\hline$n$ & 301 & 463 & 268 & 224 & 204 & 348 \\
\hline Min Age & 2 & 2 & 3 & 3 & 3 & 3 \\
\hline Max Age & 10 & 9 & 21 & 33 & 16 & 13 \\
\hline Mean Age & 4.06 & 4.17 & 4.72 & 4.78 & 4.79 & 4.86 \\
\hline$(\mathrm{SE})$ & $(0.06)^{a}$ & $(0.05)^{a}$ & $(0.10)^{b}$ & $(0.15)^{b}$ & $(0.08)^{b}$ & $(0.06)^{b}$ \\
\hline
\end{tabular}




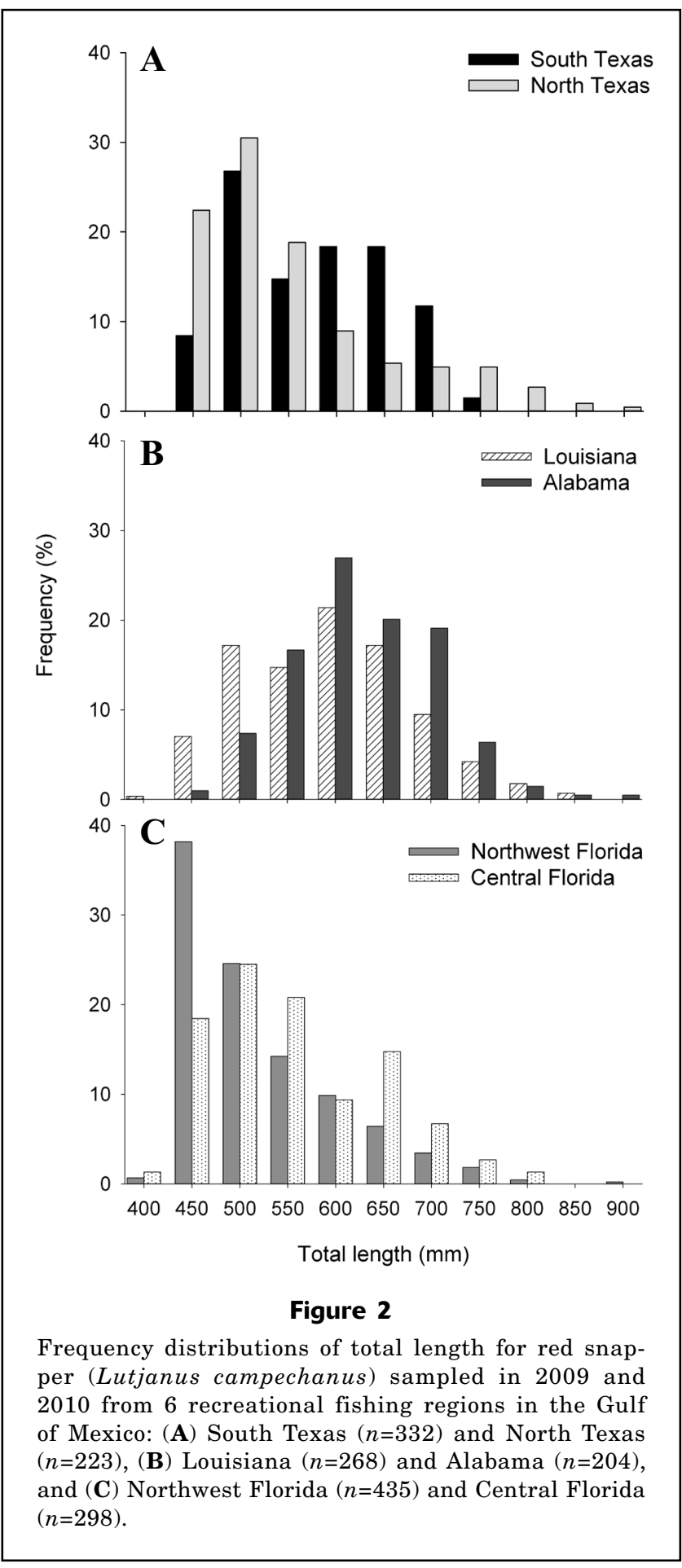

homogeneity of slopes, $F_{5 ; 1498}=2.86 ; P=0.01$; coefficient of determination $\left[r^{2}\right]=0.92$; ANCOVA test of equal intercepts, $\left.F_{5 ; 1498}=2.95 ; P=0.01 ; r^{2}=0.92\right)$; therefore, separate models were fitted for each region (Table 3 ). No significant differences were observed between the TWTL regressions for males and females (ANCOVA test of homogeneity of slopes, $F_{1 ; 1504}=0.11 ; P=0.89 ; r^{2}=0.91$;
ANCOVA test of equal intercepts, $F_{1 ; 1504}=0.13 ; P=0.87$; $r^{2}=0.91$ ).

Ages were obtained from all 1808 transverse otolith sections. After the second reading, the readers reached agreement for $91.9 \%$ of the otoliths, with an APE of $1.08 \%$ (Table 4). Among all regions, red snapper were young (mean age: 4.51 years [0.03]) and $86 \%$ of individuals were between the ages of 3 and 5 years (Fig. 3 ). Fish from the 2 Florida regions had significantly smaller mean ages than fish from the other 4 regions (Table 2); these 2 regions also had the highest proportions of young fish (72\% younger than 5 years) (Fig. 3 ). No significant differences were found between the sexes in the age distributions (KS test: $P=0.77$ ) and means (Tukey's HSD test: $P=0.76$ ).

Significant differences were observed among the regions in mean size at age for the most common ages of red snapper (Table 5). Fish from South Texas and Northwest Florida were consistently smaller in mean TL and TW at age than fish from the other regions (Fig. 4). Alabama fish were significantly larger at ages 4 and 5 than fish from the other regions. Fish from Louisiana and Central Florida were consistently larger than fish from both Texas regions and Northwest Florida and were not significantly different in mean TL at age (Table 5). Statistical comparisons of size at age for fish older than age 7 were not possible because of insufficient sample sizes.

All red snapper exhibited rapid growth until 6-8 years of age, after which growth slowed considerably (Fig. 5). Significant differences occurred among the von Bertalanffy growth models for the six regions (Table 6) but not between the sexes (likelihood ratio test $\mathrm{df}=2$; TL model: $\chi^{2}$ test $=2.18, P=0.34$;W model: $\chi^{2}$ test $=4.18$, $P=0.12$ ). All of the von Bertalanffy models differed from each other, except for the models of TL for Louisiana and Central Florida. Although significant differences were found among the growth models, pairwise comparisons of the model parameters were not reported because of the truncated range of the age data. The von Bertalanffy TL models for the North Texas and Alabama regions exhibited the largest $L_{\infty}$, and the TL models for South Texas and Northwest Florida exhibited the smallest $L_{\infty}$ and the largest growth coefficients (k) (Fig. 5A, Table 3). The von Bertalanffy growth models (both TL and TW) for North Texas, Louisiana, and Alabama produced similar growth coefficients $(k \approx 0.2)$ (Fig. 5, A and B; Table 3).

\section{Discussion}

Among all of the regions, red snapper exhibited a truncated age structure with $<1 \%$ of the sampled fish older than 10 years. A decade ago, Fischer et al. (2004) reported that $10 \%$ of red snapper examined from recreational catches of Texas, Louisiana, and Alabama were older than 6 years-a proportion that is more than double the occurrence of fish older than 6 years in our 


\section{Table 3}

Total weight (TW)-total length (TL) regression models and TL and TW von Bertalanffy growth models for red snapper (Lutjanus campechanus) sampled in 2009 and 2010 from recreational catches in 6 regions of the Gulf of Mexico: South Texas, North Texas, Louisiana, Alabama, Northwest Florida, and Central Florida.

\begin{tabular}{llll}
\hline Region & \multicolumn{1}{c}{ TW-TL model } & $\begin{array}{c}\text { TL von Bertalanffy } \\
\text { growth model }\end{array}$ & $\begin{array}{c}\text { TW von Bertalanffy } \\
\text { growth model }\end{array}$ \\
\hline South Texas & $T W=2.49 \times 10^{-8}(T L)^{2.90}$ & $T L_{t}=644.5\left(1-\mathrm{e}^{(-0.4189(t))}\right)$ & $T W_{t}=3.80\left(1-\mathrm{e}^{(-0.4185(t))}\right)^{2.90}$ \\
North Texas & $T W=7.85 \times 10^{-9}(T L)^{3.08}$ & $T L_{t}=908.2\left(1-\mathrm{e}^{(-0.1905(t))}\right)$ & $T W_{t}=10.57\left(1-\mathrm{e}^{(-0.1953(t))}\right)^{3.08}$ \\
Louisiana & $T W=1.66 \times 10^{-8}(T L)^{2.97}$ & $T L_{t}=771.0\left(1-\mathrm{e}^{(-0.2988(t))}\right)$ & $T W_{t}=7.69\left(1-\mathrm{e}^{(-0.2537(t))}\right)^{2.97}$ \\
Alabama & $T W=3.61 \times 10^{-8}(T L)^{2.85}$ & $T L_{t}=839.8\left(1-\mathrm{e}^{(-0.2747(t))}\right)$ & $T W_{t}=12.75\left(1-\mathrm{e}^{(-0.2033(t))}\right)^{2.85}$ \\
Northwest Florida & $T W=1.20 \times 10^{-8}(T L)^{3.02}$ & $T L_{t}=690.2\left(1-\mathrm{e}^{(-0.3219(t))}\right)$ & $T W_{t}=18.47\left(1-\mathrm{e}^{(-0.1539(t))}\right)^{3.02}$ \\
Central Florida & $T W=5.11 \times 10^{-9}(T L)^{3.15}$ & $T L_{t}=760.7\left(1-\mathrm{e}^{(-0.3103(t))}\right)$ & $T W_{t}=6.45\left(1-\mathrm{e}^{(-0.3104(t))}\right)^{3.15}$
\end{tabular}

study from those regions (5\%). However, it should be noted that our study did not target larger or older fish from fishing tournaments as was done in the study described in Fischer et al. (2004). The oldest fish collected in our study (33 years) was approximately 20 years younger than the oldest specimens (54 and 57 years) in the GOM reported from previous studies (Wilson and Nieland, 2001; Mitchell et al., 2004; Allman and Fitzhugh, 2007).

The predominance of small, young fish may reflect the recent decline in size at age of red snapper, as well as the age truncation of the population due to overfishing (Berkeley et al., 2004; Allman and Fitzhugh, 2007; Nieland et al., 2007). The intense overfishing that occurred from the mid-1980s to early 1990s resulted in the most depleted state of the stock (Cowan et al., 2011; SEDAR $^{5}$ ) and is a plausible reason why a scar-

\section{Table 4}

Differences between the 2 readers in average percent error (APE), coefficient of variation (CV), index of precision (D), percentages of agreement (O) for opaque annuli counts, and percentages of differences in age estimates $( \pm 1,2$, and 3 or more years) in red snapper ( $L u$ tjanus campechanus) otoliths after the first and second readings $(n=1808)$. Red snapper were sampled in 2009 and 2010 from recreational catches in 6 regions of the Gulf of Mexico: South Texas, North Texas, Louisiana, Alabama, Northwest Florida, and Central Florida.

\begin{tabular}{lcc}
\hline & $1^{\text {st }}$ reading & $2^{\text {nd }}$ reading \\
\hline APE & $1.77 \%$ & $1.08 \%$ \\
CV & 0.0177 & 0.0108 \\
D & 0.0125 & 0.0076 \\
O & $85.6 \%$ & $91.9 \%$ \\
\pm 1 & $13.54 \%$ & $6.91 \%$ \\
\pm 2 & $0.59 \%$ & $1.00 \%$ \\
\pm 3 or more & $0.18 \%$ & $0.18 \%$ \\
& &
\end{tabular}

city of older fish was observed in our study (Allman and Fitzhugh, 2007; Nieland et al., 2007). Our findings are consistent also with recent stock assessments that indicate that fish older than 8 years are rarely caught in the GOM in the red snapper fisheries (SEDAR ${ }^{1,5}$ ).

The size- and age-frequency distributions and growth models from this study indicate significant demographic differences in red snapper across the GOM. Small ( $\leq 550 \mathrm{~mm}$ TL), fast-growing fish dominated the recreational catches of South Texas and the eastern GOM. Larger (>600 mm TL), slower-growing fish constituted the majority of the catches in the northcentral and northwestern regions of the GOM, consistent with the findings of Fischer et al. (2004). Also, the larger representation of older fish and the more uniform distribution of age classes in the northern and western GOM are consistent with previous observations (Mitchell et al., 2004; Allman and Fitzhugh, 2007; $\left.\operatorname{SEDAR}^{7}\right)$. The dominant age classes (3-6 years) in our study appear to have been derived from the strong 2004, 2005, and 2006 year classes identified in the trawl surveys of the recent stock assessments $\left(\mathrm{SEDAR}^{7}\right)$. These year classes may be linked to the recent decline in the GOM shrimp fisheries and corresponding reduction in bycatch of juvenile red snapper (Cowan, 2011; $\operatorname{SEDAR}^{7}$ ). The presence of these strong year classes among all 6 regions is similar to the consistent GOM-wide year-class patterns observed by Allman and Fitzhugh (2007). This combination of demographic differences and GOM-wide year-class consistency supports recent conclusions that red snapper form a metapopulation of semi-isolated assemblages that are demographically distinct but also highly influenced by mixing between assemblages (Gold and Saillant, 2007; Patterson, 2007; Saillant et al., 2010).

Our analyses of size at age and von Bertalanffy growth models indicate differences in the growth of red

\footnotetext{
${ }^{7}$ SEDAR (SouthEast Data, Assessment, and Review). 2009. Stock assessment of red snapper in the Gulf of Mexico: SEDAR update assessment, 224 p. [Available from http://www. sefsc.noaa.gov/sedar/.]
} 


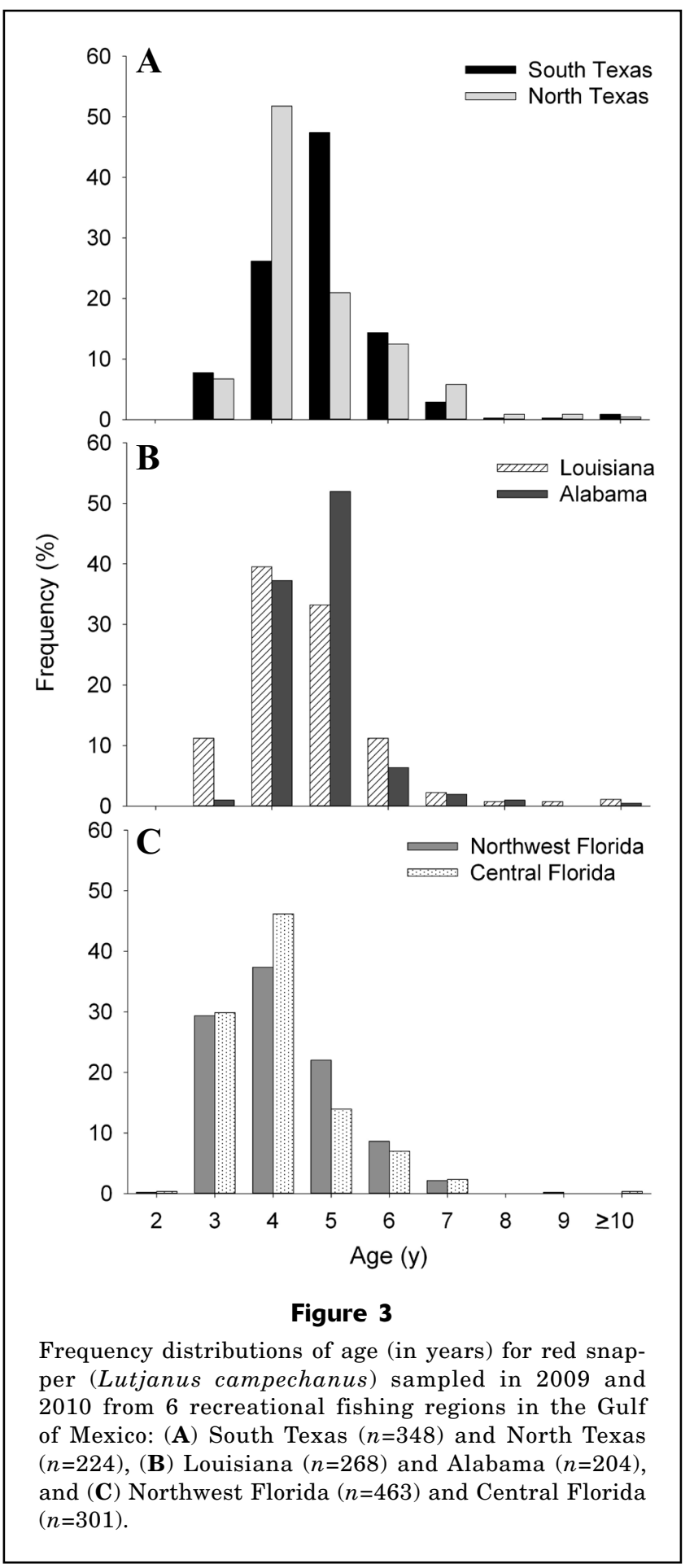

snapper across the GOM. Sample sizes were fairly consistent among the regions, allowing us to compare the trends in size at age and growth over the age ranges collected. The consistently smaller size at age, small estimates for maximum TL, and high $k$ estimates for fish from South Texas and Northwest Florida are indicative of the highly truncated age structure and over- exploitation in each region (Trippel, 1995; Rose et al., 2001; Berkeley et al., 2004; Nieland et al., 2007) and may be attributable also to variations in fishing regime (Fischer et al., 2004).

Although differences were found among the regional von Bertalanffy growth models, very few old fish were observed. As a result, the models were extrapolated beyond the range of data and may not be fully representative of each subpopulation. The absence of larger, older fish may strongly prevent the models from reaching an accurate asymptote (maximum size) (Haddon, 2001). Also, very few fish under the age of 3 years were included in our samples because of the minimum size limit on the recreational fishery ( $>406.4 \mathrm{~mm}$ maximum TL). Therefore, the models were forced through $t_{0}=0$ to more accurately predict juvenile growth, a selection that may increase $k$ estimates. Nonetheless, the $k$ estimates from this study were comparable to estimates from previous studies (Patterson et al., 2001b; Wilson and Nieland, 2001; Fischer et al., 2004).

In contrast to red snapper in South Texas, the slower-growing red snapper from North Texas appear to be more similar to fish in Louisiana and Alabama. These findings are consistent with reports of significant postsettlement movement of juveniles (0-2 years) between the northern and western GOM, as well as with otolith microchemistry analysis and larval transport studies that indicate that recruitment in the western GOM is subsidized by recruits from Louisiana (Patterson, 2007; Patterson et al., 2008; Johnson et al., 2009; Sluis, 2011). These observed differences may also be attributable to mixing of stocks between South Texas and Mexico because the Mexican stock is severely overfished and dominated by small, fast-growing fish (García et al., 2002). To date, no direct comparisons of red snapper age and growth from Mexican and U.S. waters have been made. However, in a recent otolith microchemistry study the source of recruits to the Texas continental shelf was determined to be derived from a combination of the Texas, Louisiana, and Mexico substocks (Sluis, 2011). Sluis (2011) also found a large contribution of the Louisiana substock to the eastern GOM. Therefore, the similarities observed in this study for red snapper between the Louisiana and Central Florida regions may be indicative of regional connectivity through offshore currents that flow clockwise along the outer continental shelf and potentially transport larvae and adults (Ohlmann and Niiler, 2005; Johnson et al., 2009).

The potential mechanisms for the observed demographic variation include environmental factors, fishing pressure (including localized population responses), habitat preference, and management regimes in the different regions (e.g., state regulations). Numerous environmental differences, including availability of suitable habitat, productivity of the surrounding ecosystem, and community structure could have contributed to the demographic dissimilarity among the regions. The productive, nutrient-rich waters of the Mississippi River plume have been shown to influence 


\section{Table 5}

Analyses of variance (ANOVA) and Tukey's honestly significant difference test of mean total length at age (in millimeters) and total weight at age (in kilograms) for the most common ages (3-7 years) of red snapper (Lutjanus campechanus) sampled from recreational catches in 6 regions of the Gulf of Mexico in 2009 and 2010. The 6 regions were South Texas (STX), North Texas (NTX), Louisiana (LA), Alabama (AL), Northwest Florida (NFL), and Central Florida (CFL). Each section is arranged in increasing order of mean values. Letters are used to indicate significant differences $(<0.05)$ among the means from the comparisons according to the Tukey's test. Within each row, means not connected with the same letter are significantly different.

\begin{tabular}{|c|c|c|c|c|c|c|c|c|c|c|}
\hline \multirow[b]{2}{*}{ Age } & \multicolumn{4}{|c|}{ ANOVA } & \multicolumn{6}{|c|}{ Comparisons according to Tukey's test } \\
\hline & $n$ & $\mathrm{df}$ & $F$ & $P$ & NFL & STX & NTX & CFL & LA & $\mathrm{AL}$ \\
\hline \multicolumn{11}{|c|}{ Total length at age } \\
\hline 3 & 297 & 291 & 8.17 & $<0.0001$ & $\mathrm{~A}$ & A & $\mathrm{B}$ & B & $\mathrm{B}$ & $\mathrm{B}$ \\
\hline 4 & 686 & 680 & 34.27 & $<0.0001$ & B & A & $\mathrm{B}$ & $\mathrm{C}$ & $\mathrm{AC}$ & $\mathrm{C}$ \\
\hline 5 & 536 & 530 & 18.59 & $<0.0001$ & $\mathrm{AB}$ & A & B & $\mathrm{C}$ & $\mathrm{C}$ & $\mathrm{D}$ \\
\hline 6 & 167 & 161 & 1.63 & 0.1557 & - & - & - & - & - & - \\
\hline 7 & 49 & 43 & 4.74 & 0.0015 & B & A & A & A & $\mathrm{AB}$ & A \\
\hline \multicolumn{11}{|c|}{ Total weight at age } \\
\hline 3 & 238 & 232 & 8.58 & $<0.0001$ & A & B & $\mathrm{AB}$ & $\mathrm{AB}$ & A & $\mathrm{AB}$ \\
\hline 4 & 594 & 588 & 21.75 & $<0.0001$ & A & B & A & B & B & $\mathrm{C}$ \\
\hline 5 & 482 & 476 & 15 & $<0.0001$ & $\mathrm{~A}$ & A & $\mathrm{C}$ & B & A & $\mathrm{D}$ \\
\hline 6 & 161 & 155 & 3.76 & $<0.0001$ & A & B & $\mathrm{CD}$ & D & $\mathrm{AC}$ & $\mathrm{AC}$ \\
\hline 7 & 47 & 41 & 0.9 & 0.4887 & - & - & - & - & - & - \\
\hline
\end{tabular}

\section{Table 6}

Chi-square statistics $\left(\chi^{2}\right)$, degrees of freedom (df), and $P$-values for likelihood ratio tests used with Bonferroni's correction for multiple pairwise tests, for comparing von Bertalanffy growth models of total length (TL) and total weight (TW) among the 6 regions where red snapper (Lutjanus campechanus) were sampled in the Gulf of Mexico in 2009 and 2010. The regions were South Texas (STX), North Texas (NTX), Louisiana (LA), Alabama (AL), Northwest Florida (NFL), and Central Florida (CFL). Before regional models were compared, the full von Bertalanffy growth models for TL and TW (in which regions were fitted independently) were compared with the reduced models for TL and TW (by fitting all specimens).

\begin{tabular}{|c|c|c|c|c|c|c|}
\hline \multirow[b]{2}{*}{ Model comparison } & \multicolumn{3}{|c|}{ TL model } & \multicolumn{3}{|c|}{ TW model } \\
\hline & $\chi^{2}$ & $\mathrm{df}$ & $P$ & $\chi^{2}$ & $\mathrm{df}$ & $P$ \\
\hline Full-Reduced & 291.1 & 2 & $<0.001$ & 228.49 & 2 & $<0.001$ \\
\hline NTX-STX & 87.98 & 2 & $<0.001$ & 94.78 & 2 & $<0.001$ \\
\hline NTX-NFL & 51.89 & 2 & $<0.001$ & 22.83 & 2 & $<0.001$ \\
\hline NTX-CFL & 197.44 & 2 & $<0.001$ & 92.74 & 2 & $<0.001$ \\
\hline NTX-LA & 129.31 & 2 & $<0.001$ & 26.92 & 2 & $<0.001$ \\
\hline NTX-AL & 207.75 & 2 & $<0.001$ & 89.77 & 2 & $<0.001$ \\
\hline AL-STX & 238.25 & 2 & $<0.001$ & 183.09 & 2 & $<0.001$ \\
\hline AL-NFL & 343.75 & 2 & $<0.001$ & 50.09 & 2 & $<0.001$ \\
\hline $\mathrm{AL}-\mathrm{CFL}$ & 35.17 & 2 & $<0.001$ & 13.12 & 2 & 0.001 \\
\hline AL-LA & 54.97 & 2 & $<0.001$ & 72.15 & 2 & $<0.001$ \\
\hline LA-STX & 82.62 & 2 & $<0.001$ & 76.34 & 2 & $<0.001$ \\
\hline LA-NFL & 150.64 & 2 & $<0.001$ & 20.25 & 2 & $<0.001$ \\
\hline LA-CFL & 0.94 & 2 & 0.624 & 30.49 & 2 & $<0.001$ \\
\hline STX--NFL & 58.26 & 2 & $<0.001$ & 96.05 & 2 & $<0.001$ \\
\hline STX-CFL & 38.20 & 2 & $<0.001$ & 46.96 & 2 & $<0.001$ \\
\hline NFL-CFL & 120.22 & 2 & $<0.001$ & 78.22 & 2 & $<0.001$ \\
\hline
\end{tabular}




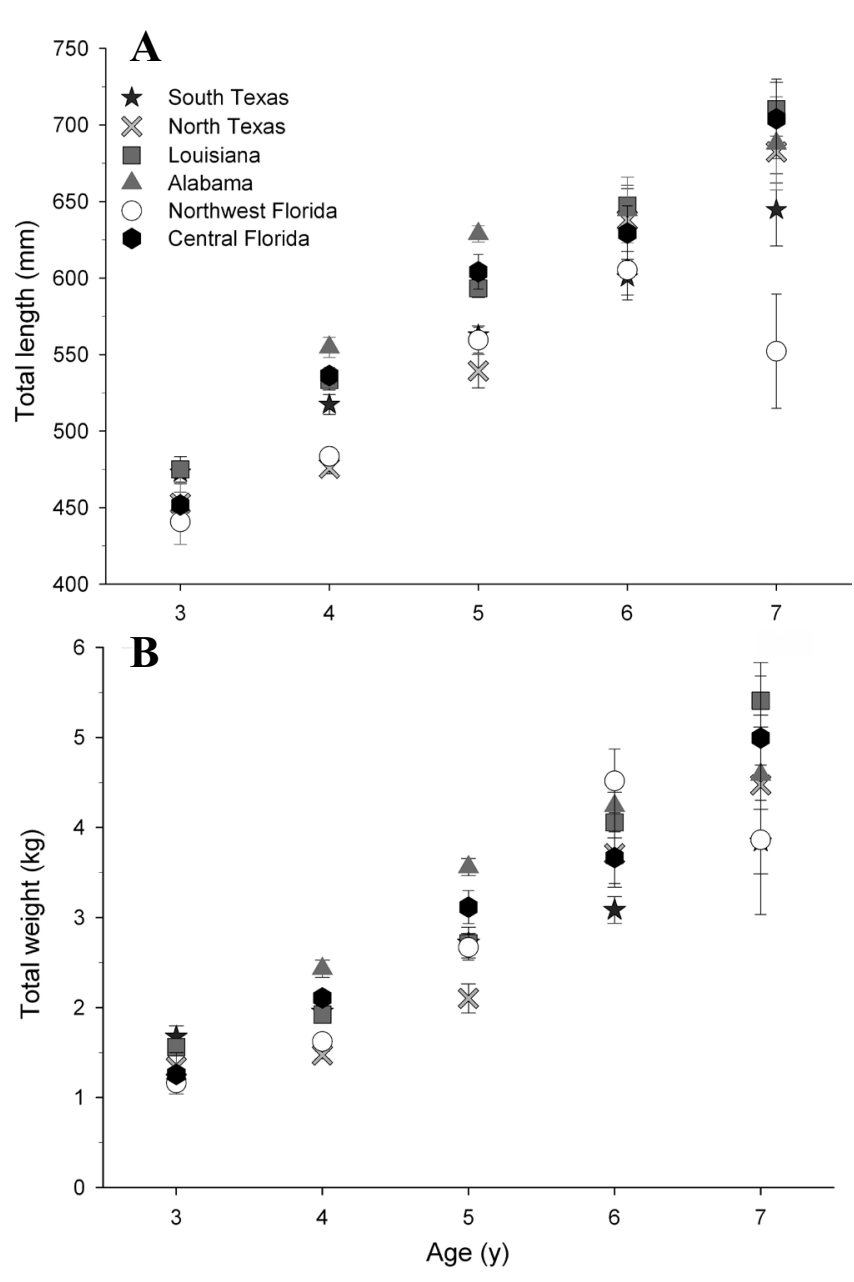

Figure 4

Mean (A) total length at age and (B) total weight at age of red snapper (Lutjanus campechanus) sampled in 2009 and 2010 from 6 recreational fishing regions in the Gulf of Mexico: South Texas, North Texas, Louisiana, Alabama, Northwest Florida, and Central Florida. Error bars represent \pm 1 standard error of the mean.

fishery production through increased growth rates of fish in the northcentral GOM when compared with other regions (DeVries et al., 1990; Grimes, 2001) and may be more conducive to growth in the Louisiana and Alabama regions (Fischer et al., 2004). Because habitat complexity and patchiness vary greatly throughout the GOM, the amount and suitability of preferred habitat, as well as prey availability, quantity, and quality, may affect the observed differences in age and growth.

Age-specific habitat preference also may play a role in the differences observed in our study. Red snapper undergo an ontogenetic shift in habitat during their first several years of life, settling on a variety of lowrelief habitats and then moving to higher relief habi- tats with greater complexity, usually into deeper waters $(>30 \mathrm{~m})$ farther offshore (Workman et al., 2002; Geary et al., 2007; Wells et al., 2008;). Previous studies have hypothesized that older red snapper ( $>6-8$ years) in northwestern GOM become less associated with reefs once they reach a predation size threshold that allows them to emigrate away from both natural and artificial structures to alternative habitats with lower relief (Render, 1995; Nieland and Wilson, 2003; Mitchell et al., 2004). Typically, recreational fishermen (in head boats and charter boats in particular) are limited by trip time and bag size; therefore, they fish relatively close to shore and presumably at shallower depths $(<40 \mathrm{~m})$, and, as a result, their catches are dominated by younger $(<4$ years) age classes (Allman and Fitzhugh, 2007; $\operatorname{SEDAR}^{7}$ ).

It is important to note also that red snapper have never been distributed uniformly across the GOM (Porch et al., 2007; SEDAR ${ }^{1}$ ). Data for commercial landings over the past century indicate a recent shift in the center of abundance from the northeastern (Alabama and Florida regions) to the northwestern GOM (Louisiana region) (Porch et al., 2007). The distribution of fishing sectors has also shifted with the center of abundance and varies significantly across the GOM. The commercial red snapper fishery and bycatch from the shrimp fishery constitute the main sources of fishing mortality in the western GOM, and the recreational fishery accounts for the greatest source of fishing mortality in the eastern GOM $\left(\mathrm{GMFMC}^{2}\right)$. In addition, variations in fishing regimes (i.e., vessel type, trip length, distance from shore, and depth fished) within the recreational fishery may influence the size and age of the fish that are caught in each region (Fischer et al., 2004). Therefore, the uneven distribution of the fishing sectors, combined with their differing management plans (quotas, size limits, and trip and bag limits) and fishing regimes, may also significantly influence the formation of demographic stocks of red snapper in the GOM.

Several compensatory responses to fishing pressure, including faster growth and early maturation, have been noted in the stock of red snapper in the GOM (Jackson et al., 2007; Nieland et al., 2007; Allman et al. ${ }^{8}$; Kulaw, 2012;) and were observed in our study. It appears that red snapper devote more of their energy as younger fish to reproduction: fish sampled in a companion study showed that $75 \%$ maturity is occurring by age 3 across the GOM (Kulaw, 2012), whereas

\footnotetext{
8 Allman, R. J., B. K. Barnett, N. Evou, R. A. Farsky, J. Keesee, and P. Carlson. 2009. Red snapper (Lutjanus campechanus) otolith aging summary 2003 to 2008. NMFS Panama City Laboratory Contribution Series 09-15, 10 p. [Available from http://www.sefsc.noaa.gov/sedar/.]
} 

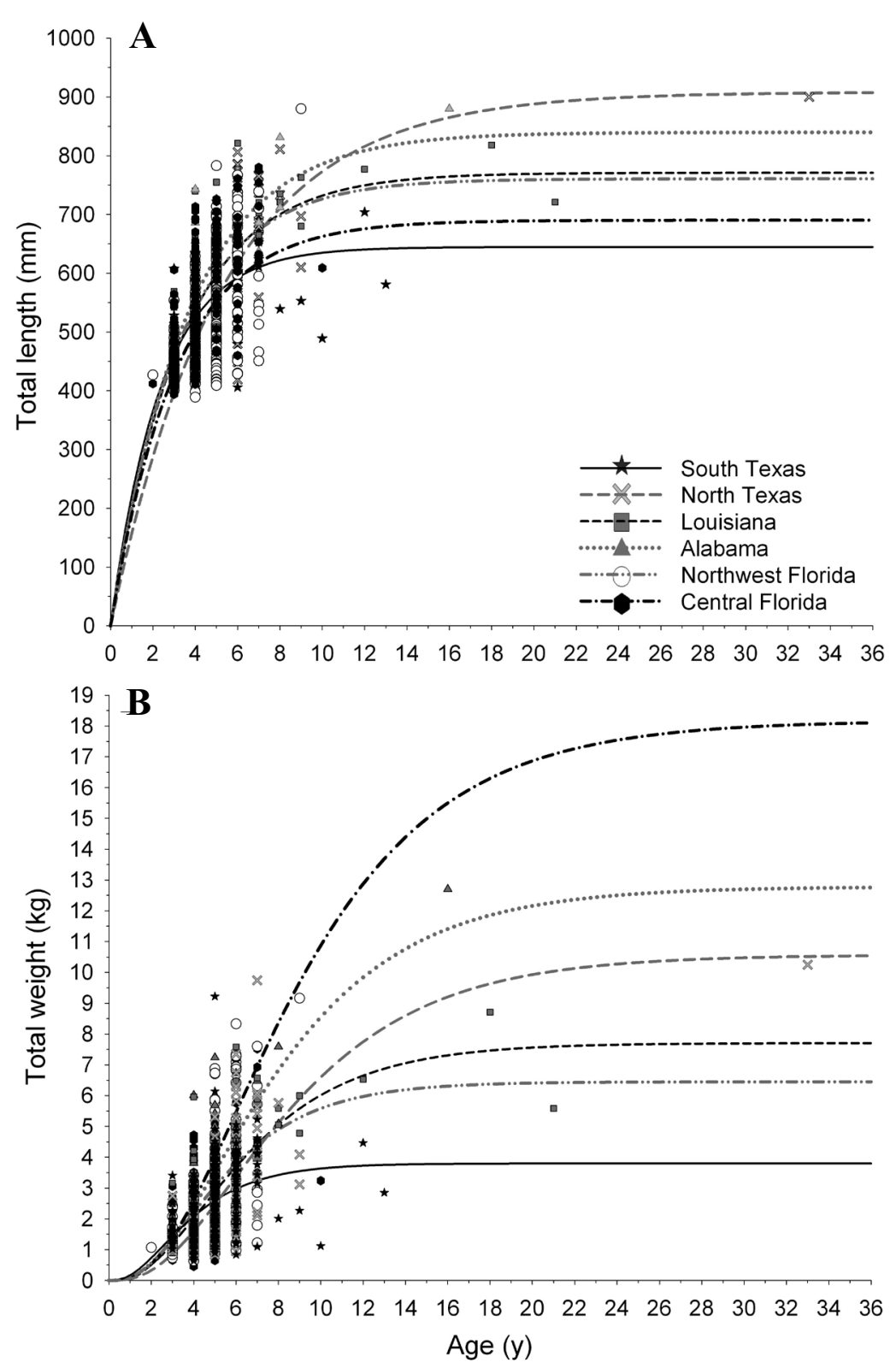

Figure 5

Observed (A) total length at age and (B) total weight at age for red snapper (Lutjanus campechanus) sampled in 2009 and 2010 from 6 recreational fishing regions in the Gulf of Mexico: South Texas, North Texas, Louisiana, Alabama, Northwest Florida, and Central Florida. Plotted lines represent the region-specific von Bertalanffy growth functions fitted to the data.

fish sampled in previous in previous studies showed that $75 \%$ maturity was reached between 4 and 8 years of age (Woods et al., 2003; Fitzhugh et al. ${ }^{9}$; Jackson et

${ }^{9}$ Fitzhugh, G. R., M. S. Duncan, L. A. Collins, W. T. Walling, and D. W. Oliver. 2004. Characterization of red snapper (Lutjanus campechanus) reproduction: for the 2004 Gulf of Mexico SEDAR. NMFS Southeast Fisheries Science Center al., 2007). Truncating the age distribution of the stock decreases its reproductive potential and limits the rate of population recovery because fecundity increases with size and age and longevity extends reproduc-

Panama City Laboratory Contribution Series 04-01, 29 p. [Available from http://www.sefsc.noaa.gov/sedar/.] 
tion across a long period of time (Trippel et al., 1997; Berkeley et al., 2004; Palumbi, 2004; Kulaw, 2012).

\section{Conclusions}

This study documented the highly truncated age structure of the recreational catches of red snapper and highlighted the demographic differences in size, age, and growth of this species across the GOM. The potential mechanisms in the observed demographic variation include environmental differences, fishing pressure, habitat preference, and management regimes; however, no definitive conclusion about cause and effect can be made. Implications of these differences along with the theory that red snapper form a metapopulation in the GOM should be considered in future stock assessments and management decisions.

The most recent stock assessment indicates that red snapper in the western GOM are beginning to recover from overfishing (SEDAR $\left.{ }^{5}\right)$. However, we documented on the basis of recreational catches across the GOM that red snapper continue to exhibit a severely truncated age structure. It is expected that as the stock rebuilds, there will be a shift to an older age structure (Allman and Fitzhugh, 2007; SEDAR ${ }^{5}$ ). An increase in red snapper biomass has been observed in the fisheries; however, an age shift was not readily apparent in our study, the latest stock assessments, or other recent studies (Allman and Fitzhugh, 2007; SEDAR ${ }^{5}$ ). Identification and protection of the strong year classes of 2004-06 will allow for stock recovery and help eliminate the truncated age structure as more fish reach maximum spawning potential (Berkeley et al., 2004; Palumbi, 2004).

\section{Acknowledgments}

Funding for this research was provided by the U.S. Department of Commerce Marine Fisheries Initiative (MARFIN grant NA08NMF4330409). We appreciate the field support from M. Sluis, G. Harwell, E. Roche, and many others. We offer our gratitude to A. Fischer for training our otolith readers and D. Kulaw for assistance in sampling and counting annuli. We also thank the numerous fishermen who allowed us to sample their catches. Finally, we would like to thank K. Simonsen and several anonymous reviewers for constructive reviews of this article.

\section{Literature cited}

Allman, R. J., and G. R. Fitzhugh.

2007. Temporal age progressions and relative year-class strength of Gulf of Mexico red snapper. Am. Fish. Soc. Symp. 60:311-328.
Allman, R. J., L. A. Lombardi-Carlson, G. R. Fitzhugh, and W. A. Fable.

2002. Age structure of red snapper (Lutjanus campechanus) in the Gulf of Mexico by fishing mode and region. Proc. Gulf Caribb. Fish. Inst. 53:482-495.

Beamish, R. J., and D. A. Fournier.

1981. A method for comparing the precision of a set of age determinations. Can. J. Fish. Aquat. Sci. 38:982-983.

Beckman, D. W., G. R. Fitzhugh, and C. A. Wilson.

1988. Growth rates and validation of age estimates of red drum, Sciaenops ocellatus, in a Louisiana salt marsh impoundment. Contrib. Mar. Sci. 30:93-98.

Berkeley, S. A., M. A. Hixon, R. J. Larson, and M. S. Love. 2004. Fisheries sustainability via protection of age structure and spatial distribution of fish populations. Fisheries 29:23-32.

Camper, J. D., R. C. Barber, L. R. Richardson, and J. R. Gold. 1993. Mitochondrial DNA variation among red snapper (Lutjanus campechanus) from the Gulf of Mexico. Mol. Mar. Biol. Biotechnol. 3:154-161.

Chang, W. Y. B.

1982. A statistical method for evaluating the reproducibility of age determination. Can. J. Fish. Aquat. Sci. 39:1208-1210.

Cowan, J. H., Jr., R. L. Shipp, H. K. Bailey IV, and D. W. Haywick.

1995. Procedure for rapid processing of large otoliths. Trans. Am. Fish. Soc. 124:280-282.

Cowan, J. H., Jr., C. B. Grimes, W. F. Patterson III, C. J. Walters, A. C. Jones, W. J. Lindberg, D. J. Sheehy, W. E. Pine III, J. E. Powers, M. D. Campbell, K. C. Lindeman, S. L. Diamond, R. Hilborn, H. T. Gibson, and K. A. Rose.

2011. Red snapper management in the Gulf of Mexico: science- or faith-based? Rev. Fish Biol. Fish. 21:187-204.

DeVries, D. A., C. B. Grimes, K. L. Lang, and D. B. White. 1990. Age and growth of king and spanish mackerel larvae and juveniles from the Gulf of Mexico and U.S. South Atlantic Bight. Environ. Biol. Fishes 29:135-143.

Fischer, A. J., C. A. Wilson, and D. L. Nieland.

2002. Age and growth of red snapper, Lutjanus campechanus, in the northwestern Gulf of Mexico: implications to the unit stock hypothesis. Proc. Gulf Caribb. Fish. Inst. 53:496-506.

Fischer, A. J., M. S. Baker Jr., and C. A. Wilson.

2004. Red snapper (Lutjanus campechanus) demographic structure in the northern Gulf of Mexico based on spatial patterns in growth rates and morphometrics. Fish. Bull. 102:593-603.

García, C. M., M. G. Andrade, and J. C. Espinoza.

2002. Análisis de la Pesqueria de Huachinango (Lutjanus campechanus) en el Banco de Campeche. Proc. Gulf Caribb. Fish. Inst. 53:507-515.

Geary, B. W., J. J. Mikulas Jr., J. R. Rooker, A. M. Landry Jr., and T. M. Dellapenna.

2007. Patterns of habitat use by newly settled red snapper in the northwestern Gulf of Mexico. Am. Fish. Soc. Symp. 60:25-38.

Gold, J. R., and E. Saillant.

2007. Population structure of red snapper in the Northern Gulf of Mexico. Am. Fish. Soc. Symp. 60:201-216. 
Gold, J. R., F. Sun, and L. R. Richardson.

1997. Population structure of red snapper from the Gulf of Mexico as inferred from analysis of mitochondrial DNA. Trans. Am. Fish. Soc. 126:386-396.

Gold, J. R., E. Pak, and L. R. Richardson.

2001. Microsatellite variation among red snapper $(\mathrm{Lu}$ tjanus campechanus) from the Gulf of Mexico. Mar. Biotechnol. 3:293-304.

Gold, J. R., G. Voelker, and M. A. Renshaw.

2011. P hylogenetic relationships of tropical western Atlantic snappers in subfamily Lutjaninae (Lutjanidae: Perciformes) inferred from mitochondrial DNA sequences. Biol. J. Linn. Soc. 102:915-929.

Gomes, G., I. Sampaio, and H. Schneider.

2012. Population structure of Lutjanus pupureus (Lutjanidae-Perciformes) on the Brazilian coast: further existence evidence of a single species of red snapper in the western Atlantic. An. Acad. Bras. Cienc. 84:979-999.

Goodyear, C. P.

1997. Fish age determined from length: an evaluation of three methods using simulated red snapper data. Fish. Bull. 95:39-46.

Grimes, C. B.

2001. Fishery production and the Mississippi River discharge. Fisheries 26:17-26.

Haddon, $\mathrm{H}$.

2001. Modelling and quantitative methods in fisheries, 406 p. Chapman \& Hall/CRC, Boca Raton, FL.

Hoese, H. D., and R. H. Moore.

1998. Fishes of the Gulf of Mexico, $2^{\text {nd }}$ ed., 416 p. Texas A\&M Univ. Press, College Station, TX.

Jackson, M. W., J. H. Cowan Jr., and D. L. Nieland.

2007. Demographic differences in northern Gulf of Mexico red snapper reproductive maturation: implication for the unit stock hypothesis. Am. Fish. Soc. Symp. 60:217-227.

Johnson, D. R., H. M. Perry, J. Lyczkowski-Shultz, and D. S.

Hanisko.

2009. Red snapper larval transport in the northern Gulf of Mexico. Trans. Am. Fish. Soc. 138:458-470.

Kimura, D. K.

1980. Likelihood methods for the von Bertalanffy growth curve. Fish. Bull. 77:765-776.

Kulaw, D.

2012. Habitat- and region-specific reproductive biology of female red snapper (Lutjanus campechanus) in the Gulf of Mexico. M.S. thesis, 165 p. Louisiana State Univ., Baton Rouge, LA.

Mitchell, K. M., T. Henwood, G. R. Fitzhugh, and R. J. Allman. 2004. Distribution, abundance, and age structure of red snapper (Lutjanus campechanus) caught on research longlines in U.S. Gulf of Mexico. Gulf Mex. Sci. 22:164-172.

Nieland, D. L., and C. A. Wilson.

2003. Red snapper recruitment to and disappearance from oil and gas platforms in the northern Gulf of Mexico. Am. Fish. Soc. Symp. 36:73-81.

Nieland, D. L., C. A. Wilson III, and A. J. Fischer.

2007. Declining size at age among red snapper in the northern Gulf of Mexico off Louisiana, USA: recovery or collapse? Am. Fish. Soc. Symp. 60:329-335.

Nowling, L., R. W. Gauldie, J. H. Cowan Jr., and E. De Carlo. 2011. Successful discrimination using otolith microchemistry among samples of red snapper Lutjanus campechanus from artificial reefs and samples of L. campechanus taken from nearby oil and gas platforms. Open Fish Sci. J. 4:1-9.

Ohlmann, J. C., and P. P. Niiler.

2005. Circulation over the continental shelf in the northern Gulf of Mexico. Prog. Oceanogr. 64:45-81.

Palumbi, S. R.

2004. Why mothers matter. Nature 430:621-622.

Patterson, W. F., III, J. C. Watterson, R. L. Shipp, and J. H. Cowan Jr.

2001a. Movement of tagged red snapper in the northern

Gulf of Mexico. Trans. Am. Fish. Soc. 130:533-545.

Patterson, W. F., III, J. H. Cowan Jr., C. A. Wilson, and R. L. Shipp.

2001b. Age and growth of red snapper, Lutjanus campechanus, from an artificial reef area off Alabama in the northern Gulf of Mexico. Fish. Bull. 99:617-627.

Patterson, W. F., III.

2007. A review of movement in Gulf of Mexico red snapper: implications for population structure. Am. Fish. Soc. Symp. 60:245-261.

Patterson, W. F., III, J. H. Cowan Jr., C. A. Wilson, and Z. Chen. 2008. Temporal and spatial variability in juvenile red snapper otolith elemental signatures in the northern Gulf of Mexico. Trans. Am. Fish. Soc. 137:521-532.

Porch, C. E.

2007. An assessment of the red snapper fishery in the U.S. Gulf of Mexico using a spatially-explicit age-structured model. Am. Fish. Soc. Symp. 60:355-384.

Porch, C. E., S. C. Turner, and M. J. Schirripa.

2007. Reconstructing the commercial landings of red snapper in the Gulf of Mexico from 1872-1963. Am. Fish. Soc. Symp. 6:337-353.

Render, J. H.

1995. The life history (age, growth and reproduction) of red snapper (Lutjanus campechanus) and its affinity for oil and gas platforms. Ph.D. diss., 76 p. Louisiana State Univ., Baton Rouge, LA.

Rose, K. A., J. H. Cowan Jr., K. O. Winemiller, R. A. Myers, and R. Hilborn.

2001. Compensatory density dependence in fish populations: importance, controversy, understanding and prognosis. Fish Fish. 2:293-327.

Saillant, E., and J. R. Gold.

2006. Population structure and variance effective size of red snapper (Lutjanus campechanus) in the northern Gulf of Mexico. Fish. Bull. 104:136-148.

Saillant, E., S. C. Bradfield, and J. R. Gold.

2010. Genetic variation and spatial autocorrelation amoung young-of-the-year red snapper (Lutjanus campechanus) in the northern Gulf of Mexico. ICES J. Mar. Sci. 67:1240-1250.

Sluis, M. Z.

2011. Variability in red snapper otolith microchemistry among Gulf of Mexico regions. Ph.D. diss., 132 p. Louisiana State Univ., Baton Rouge, LA.

Sluis, M. Z., B. K. Barnett, W. F. Patterson III, J. H. Cowan, Jr, and A. M. Shiller.

2012. Discrimination of juvenile red snapper otolilth chemical signatures from Gulf of Mexico nursery regions. Mar. Coast. Fish. 4:587-598.

Tate, M. T., and R. C. Clelland.

1957. Non-parametric and shortcut statistics in the social, biological, and medical sciences, 171 p. Interstate Printers and Publishers Inc., Danville, IL. 
Trippel, E. A.

1995. Age at maturity as a stress indicator in fisheries. Bioscience 45:759-771.

Trippel, E. A., O. S. Kjesbu, and P. Solemdal.

1997. Effects of adult age and size structure on reproductive output in marine fishes. In Early life history and recruitment in fish populations (R. C. Chambers and E. A. Trippel, eds.), p. 31-62. Chapman \& Hall, London.

Wells, R. J. D., J. H. Cowan Jr., W. F. Patterson III, and C. J. Walters.

2008. Effect of trawling on juvenile red snapper (Lutjanus campechanus) habitat selection and life history parameters. Can. J. Fish. Aquat. Sci. 65:2399-2411.

Wilson, C. A., and D. L. Nieland.

2001. Age and growth of red snapper, Lutjanus campechanus, from the northern Gulf of Mexico off Louisiana. Fish. Bull. 99:653-664.

Woods, M. K., A. J. Fischer, J. H. Cowan Jr., and D. L. Nieland. 2003. Size and age at maturity of female red snapper Lutjanus campechanus in the northern Gulf of Mexico. Proc. Gulf Caribb. Fish. Inst. 54:526-537.

Workman, I., A. Shah, D. Foster, and B. Hataway.

2002. Habitat preferences and site fidelity of juvenile red snapper (Lutjanus campechanus). ICES J. Mar. Sci. 59:S43-S50. 